\title{
14
}

\section{The Technical Jekyll and the Political Hyde}

\author{
The Constitutional Law and Politics of Scotland's \\ Independence 'Neverendum'
}

\author{
Andrew Tickell
}

\section{A disaster averted, a tension unresolved}

On 15 October 2012, the UK Supreme Court was deprived of one of its landmark constitutional cases, its Secession of Quebec reference. ${ }^{1}$ In St Andrew's House in Edinburgh, Prime Minister David Cameron, Secretary of State for Scotland Michael Moore, and First and Deputy First Ministers Alex Salmond and Nicola Sturgeon put their names to the Agreement between the United Kingdom Government and the Scottish Government on a Referendum on Independence for Scotland. The product of private, backroom negotiations between the two governments, what became known as the 'Edinburgh) Agreement' ended months of uncertainty and legal debate over whether Holyrood had the competence to legislate for a referendum on Scottish independence. Paving the way for a 'legal, fair and decisive' poll, the two governments agreed that Westminster would intervene to 'put it beyond doubt that the Scottish Parliament can legislate for that referendum'.

This memorandum was accompanied by a draft Order under section 30 of the Scotland Act 1998, which set out how the devolution legislation would be amended to achieve these ends. Holyrood would be invested with a categorical but time-limited power to legislate for a referendum on Scottish independence. ${ }^{3}$ This legal security was purchased with a series of policy concessions to the coalition government's constitutional agenda, ruling out a multi-option referendum including a second question about further devolution, and involving the Electoral Commission in the poll's scrutiny and regulation. The Agreement also set out principles which would shape the Scottish Parliament's subsequent legislation, modelling the referendum on the Political Parties, Elections and Referendums

1 [1998] 2 SCR 217.

2 Agreement between the United Kingdom Government and the Scottish Government on a referendum on independence for Scotland (2012) 2.

3 The Scotland Act 1998 (Modification of Schedule 5) Order 2013 No. 242. 
Act $2000,{ }^{4}$ and devolving responsibility to Holyrood for determining the franchise, the campaign finance rules, and the precise referendum question and the timing of the poll. ${ }^{5}$

Politicians on both sides of the national question, civil servants, and anybody anxious not to see the referendum embroiled in potentially protracted litigation breathed a sigh of relief. Only constitutional lawyers might — privately_admit to any professional disappointment that the lively vires debate which had crackled for months on airwaves, in print, parliament, universities, and on blogs would not now be tested before the UK Supreme Court. The crux of the dispute concerned the interpretation of the Scotland Act 1998. The Scottish National Party had been re-elected in 2011 with a majority of MSPs in the Scottish Parliament, having stood on a manifesto that:

We think the people of Scotland should decide our nation's future in a democratic referendum and opinion polls suggest that most Scots agree. We will, therefore, bring forward our Referendum Bill in this next Parliament. A yes vote will mean Scotland becomes an independent nation and we can then begin the job of delivering the better country we all know Scotland can be. ${ }^{6}$

But did Holyrood enjoy the legislative competence to realize this manifesto commitment, democratically endorsed by the Scottish electorate? Under section 29(1) of the Scotland Act, Acts of the Scottish Parliament which are outside legislative competence are not law. Amongst other limits on Holyrood's power, including compatibility with Convention rights and the law of the European Union, ${ }^{7}$ an Act will fall outside the Parliament's competence where it 'relates to reserved matters' set out in Schedule 5 of the Act. ${ }^{8}$ Part 1 of the Schedule reserves 'aspects of the constitution' to Westminster, including 'the Union of the Kingdoms of Scotland and England'.' The Scotland Act provides guidance on how courts are to approach adjudication under this section. 'Whether a provision of an Act of the Scottish Parliament relates to a reserved matter' is to be determined 'by reference to the purpose of the provision, having regard (among other things) to its effect in all the circumstances'. ${ }^{10}$ This test must be read alongside the interpretative duty imposed on the court by section 101, which provides that any Act of the Scottish Parliament 'which could be read in such a way as to be outside competence' must be 'read as narrowly as is required for it to be within competence, if such a reading is possible'. ${ }^{11}$

In the months preceding the Edinburgh Agreement, the Scottish Government claimed that its referendum bill could withstand the rigour of

\footnotetext{
${ }^{4}$ Incorporating some of the inadequacies of that Act. Cf. A. Tickell, 'Regulating \#indyref: Social Media and the Scottish Independence Referendum Act 2013' (2014) 18 Edinburgh Law Review 406-10.

5 S. Tierney, 'The Referendum on Scottish Independence: A Process as well as an Event' (2014) 18 Edinburgh Law Review 245-50.

6 Scottish National Party, Scottish National Party Manifesto (2011) 28.

7 Scotland Act 1998, s. 29(2)(d). $\quad 8$ Scotland Act 1998, s. 29(2)(b).

9 Scotland Act 1998, Sched. 5, para. 1(b). $\quad 10$ Scotland Act 1998, s. 29(3).

11 Scotland Act 1998, s. 101(1) and (2).
} 
this test. They suggested the bill fell within legislative competence. ${ }^{12}$ The bill's detractors, including independent legal analysts and scholars, the UK Government, and House of Lords and Commons committees, took the diametrically opposite view. ${ }^{13}$ They argued that, having regard to its 'purpose and effect', any referendum bill would 'relate to' the reserved matter of 'the Union of the Kingdoms' and accordingly, fall outwith Holyrood's legislative competence. Professor Page summarized the critical arguments on the vires of any referendum Bill crisply:

When regard is had to the effect of the legislation, including its effect on the reserved matter of the Union ... it becomes clear in my opinion that its true purpose is not to solicit the views of people in Scotland on a proposal about the way Scotland is governed, but to further the Scottish government's aim of achieving independence. A referendum is not a disinterested exercise in opinion gathering. It is embarked upon for a purpose-in this case to mobilize Scottish opinion in support of independence. ${ }^{14}$

Also critical was the UK Supreme Court's (2011) decision in AXAv Lord Advocate. ${ }^{15}$ Leading judgments from Lords Hope and Reed loosened Scotland's historically restrictive rules on standing, ${ }^{16}$ which required petitioners to demonstrate 'title and interest' to sue. ${ }^{17}$ In $A X A$, the Supreme Court liberalized the rules, ${ }^{18}$ requiring litigants to demonstrate only a 'sufficient interest' to bring judicial review proceedings, to be determined on the facts and circumstances of individual cases. ${ }^{19}$ While a petitioner might struggle to establish a particular 'title and interest' to review the vires of the referendum, a very large number of people could be seen as having a 'sufficient interest to do so'. ${ }^{20}$ Litigation seemed inevitable.

The Edinburgh Agreement was an act of statesmanship by which potentially damaging and divisive court proceedings were avoided. Yet it represented only a temporary compromise between political claims of a right to Scottish

12 Scottish Government, Scotland's Future: Draft Referendum (Scotland) Bill Consultation Paper (2010); Scottish Government, Your Scotland, Your Referendum Consultation (2012).

13 See, amongst other examples, UK Government, Scotland's Constitutional Future: Responses to the Consultation (2012); Scottish Affairs Committee, The Referendum on Separation for Scotland: making the process legal (HC 2012-13, 542); J. Wallace, Advocate General, 'Approaching the Independence Referendum: The Legal Issues', Speech at the University of Glasgow (2 October 2012); J. Wallace, Advocate General, 'Looking Forwards: To a Legal, Fair and Decisive Referendum', Speech at Balfour and Manson, Aberdeen (24th May 2012); UK Government, Scotland's Constitutional Future: A Consultation on Facilitating a Legal, Fair and Decisive Referendum on Whether Scotland Should Leave the United Kingdom (2012); House of Lords Committee on the Constitution, Referendum on Scottish Independence Report (HL 2010-12, 263).

14 Quoted in Scottish Affairs Committee, The Referendum on Separation (n. 13) at para. 29.

15 AXA General Insurance Ltd and Ors $v$ the Lord Advocate [2011] UKSC 46.

16 See, generally, A. McHarg, 'Analysis: Axa General Insurance Ltd v Lord Advocate' (2012) 16 Edinburgh Law Review 224-60.

17 D \& J Nicolv Dundee Harbour Trustees 1915 SC (HL) 7.

18 See also C. McCorkindale, 'Public Interest Litigants in the Court of Session' (2015) 19 Edinburgh Law Review 247-53.

19 AXA General Insurance Ltd and Ors $v$ the Lord Advocate [2011] UKSC 46 at paras 169-70.

$20 A X A($ n. 19) at para. 147. 
self-determination, and legal uncertainty about the Scottish Parliament's power unilaterally to embark on a democratic process resulting in independence. The 2012 pact left these tensions fundamentally unresolved. When the bells of Hogmanay tolled on 31 December 2014, the temporary authority extended to the Scottish Parliament lapsed, largely unmarked, unremarked, and unnoticed. If the Yes campaign had carried the day on 18 September 2014, these questions would be consigned to the tome of nice points of law forgotten to history. The relevance of the UK devolved and constitutional order would have receded. Negotiated independence would, in all probability, have followed. Scottish politicians would be working in early days of a different nation. Having voted to remain in the Union, however, the unresolved questions of 2012 are now of more than academic interest.

\section{2014: Legal, fair, but decisive?}

Professor Jeffery has argued that 'it did not take long for some who had campaigned for Scottish independence to begin envisaging a second referendum'. ${ }^{21}$ This diagnosis is arguably too limited. In the months that followed the vote, it did not take long both for proponents and oppenents of Scottish independence to begin to discuss the possible timing, triggers for, and legitimacy of a second referendum on Scottish independence. 'The prospect of a 'neverendum' is now upon us. For some, this will be a source of considerable anxiety and unhappiness. For others, it is the object of lively anticipation. For most, it now seems inevitable. Social research by Survation, published on 8 July 2015, suggested that only 20.4 per cent of the Scottish populace wished never to see another independence referendum. Only 38 per cent of those who voted No in September 2014 told the pollster there should never be a second referendum. ${ }^{22}$ The Scottish National Party's plans_-or lack of plans_-for a second plebiscite formed a central plank of the Labour Party's UK general election campaign in the spring of 2015. Scottish Labour sought to attract voters opposed to any rerun of the 2014 poll by arguing Scotland would be 'turbo-charged towards a second referendum' if significant numbers of SNP members were returned to Westminster. ${ }^{23}$ In the wake of the 2015 general election, the unseated former leader of the Scottish Labour Party, Jim Murphy, claimed that 'there will be a second independence referendum' because 'David Cameron will stumble into giving the SNP the excuse for one'. ${ }^{24}$ Scottish Conservative leader, Ruth Davidson, has said that 'if the SNP puts in its

21 C. Jeffery, 'Constitutional Change-Without End?' (2015) 86 Pol Q 275 at 275.

22 Survation, Issues Poll Prepared on Behalf of the Scottish Daily Mail (2015) 23 accessible at $<$ http://survation.com/wp-content/uploads/2015/07/Full-SDM-tables-1c0d8h4.pdf> last accessed 29 November 2015.

23 'Murphy: Scotland will be turbo-charged towards a second indyref if over 50 per cent of Scots vote for SNP' Herald (28 April 2015).

24 D. Maddox, 'Jim Murphy: There will be second indyref' Scotsman (15 June 2015). 
manifesto that it has an intention to hold a second referendum, and if it wins an outright majority, I think it does have a mandate to hold one', arguing that 'in the longer term, Westminster saying "No you cannae" will not play well in Scotland, and I think that it would damage the unionist cause'. ${ }^{25}$

Despite repeated claims during the 2015 campaign that 'there is no second independence referendum on the immediate horizon', SNP leader Nicola Sturgeon was pressed by the media and her political opponents on the circumstances which, in her view, could justify calling a second referendum. ${ }^{26}$ The First Minister maintained that 'something material would have to change in terms of the circumstances or public opinion before I think it would be appropriate to have a proposal for a referendum'-giving UK exit from the European Union as one example of a 'material change' of this kind. ${ }^{27}$ In the months that have followed the SNP landslide, several SNP figures have identified different constitutional causae belli which might justify calling a second referendum, from renewing Trident, failing adequately to reflect their preferences in the third Scotland Bill, and changes to the standing orders of the House of Commons which curtail the voting rights of Scottish MPs concerning primary and secondary legislation designated by the Speaker as England or England and Wales only-English votes for English laws. At time of writing, the Scottish Government's public view on the possibility of holding another referendum has stabilized into the following formula:

The timing of any future referendum is entirely a matter for the people of Scotland to decide - the people, not politicians, are in charge at every stage of the process. The First Minister has made clear we are not planning another referendum, but equally has made it clear that it is not in the gift of anypolitician and party to rule it out indefinitely. ${ }^{28}$

Those familiar with debates about the proper scope of self-determination and the right to secede under international law will recognize the fundamental structure of these two strains of argument, the one emphasizing triggering grounds for secession, the second emphasizing self-determination as an inherent, fundamental right which can be exercised irrespective of transient events and circumstances. Thus far, the case for a second referendum has been articulated in both formats. Parliamentary debates since the 2015 election, from all sides of the Westminster Parliament, have meditated on the Union's continuing frailty. Op-eds continue to be written and talking heads continue to talk as if a second independence referendum is inevitable, and all that remains to be determined is when the poll takes place. As Cairney has argued, it has become increasingly clear since September

25 D. Aitkenhead, 'Ruth Davidson, Scottish Conservative leader: "Up here, you have to make more of an effort" ' Guardian (12 June 2015).

26 N. Sturgeon, A Conversation With Nicola Sturgeon (Council on Foreign Relations 2015).

27 BBC News, 'Election 2015: Sturgeon says only "material change" could spark Scots referendum' (8 April 2015) accessible at <http://www.bbc.co.uk/news/election-2015-scotland-32222806> last accessed 1 June 2015.

28 'SNP MP asks Scottish Secretary: do you have any contingency plans in case second indyref is held' Herald (20 July 2015). 
2014 that the 'result was not decisive and did not settle the matter'-even for the short and medium term. ${ }^{29}$ The prospect of a Scottish 'neverendum', or at least expectations that a second referendum can and will be held at some point in the none-too-distant future, are mainstream.

Curiously absent from this political speculation and argument, however, is any reflection on the fraught process which laid the legal foundations for the 2014 poll, and the constitutional tensions it expressed. Fundamental questions about the legal and constitutional status of Scottish secession referendums, deferred but not resolved by the Edinburgh Agreement of 2012, now return with a vengeance. Can the Scottish Parliament lawfully hold a referendum on its own authority? What conjunction of circumstances might justify a second referendum? And who decides? Sunstein characterizes constitutions as 'precommitment strategies, designed to foreclose debate over certain fundamental questions'. ${ }^{30}$ As Mac Amhlaigh has suggested, unless the Scotland Act is radically reordered to put the question beyond doubt, the legality of future referendums remains 'an archetypical "hard case"' ${ }^{31}$ Yet it is a hard case which Westminster currently seems disinclined to answer in any decisive way. In contrast with the Canadian Clarity Act of 2002, which explicitly anticipated the prospect of future Québécois secession referendum, specifying when the Canadian federal government would consider such a poll binding upon it, the United Kingdom now seems determined to maintain the ambiguous status quo and to avoid 'pre-commitment' to the legality, or conditions for the legality, of a future referendum of any kind on the national question. Why? Cui bono?

\section{Against constitutionalizing a right to secession}

One influential defence of rejecting legal and constitutional pre-commitments to the legality of secession polls can be found in the writings of the American constitutional scholar, Professor Cass Sunstein. Writing as the rubble of the Berlin Wall settled, as the Soviet Union unravelled, and new constitutional orders emerged in the Caucuses, the Baltic republics, and the Balkans, in 'Constitutionalism and Secession' Sunstein is preoccupied by questions of constitutional design in multi-ethnic and multinational states. His point, however, is not a parochial one. Drawing on the American constitutional experience of federation and subsequent civil war, Sunstein argues that 'whether or not secession might be justified as a matter of politics or morality, constitutions ought not to include a right to secede'

29 P. Cairney, 'The Scottish Independence Referendum: What are the Implications of a No Vote?’ (2015) 86 Pol Q 186-91.

30 C. R. Sunstein, 'Constitutionalism and Secession' (1991) 58 University of Chicago Law Review 633 at 635 .

31 C. Mac Amhlaigh '... yes, but is it legal? The Scottish Independence Referendum and the Scotland Act 1998' (UK Constitutional Law blog, 1 December 2012) accessible at <http:// ukconstitutionallaw.org/2012/01/12/cormac-mac-amhlaigh-yes-but-is-it-legal-the-scottishindependence-referendum-and-the-scotland-act-1998/> last accessed 29 November 2015. 
and 'courts should not find such a right to be implicit in constitutions'. ${ }^{32}$ Why not? 'To place such a right in a founding document', he argues, would

increase the risks of ethnic and factional struggle; reduce the prospects for compromise in deliberation in government; raise the stakes of day-to-day political decisions; introduce irrelevant and illegitimate considerations into those decisions; create dangers of blackmail, strategic behaviour, and exploitation; and, most generally, endanger the prospects for long-term self-governance. ${ }^{33}$

Sunstein is particularly concerned about the emergence of a national politics, framed by what Weinstock has described as 'trigger-happy secessionists', ${ }^{34}$ where 'a threat to secede could under certain conditions be plausible at any given time, allowing the exit of the subunit from the nation to be a relevant factor in every important decision'. ${ }^{35}$ A decade on, a number of the multi-ethnic, multinational states Sunstein discussed had already disintegrated. In short order, Yugoslavia unravelled into Croatia, Slovenia, Macedonia, Bosnia and Hezegovina, Serbia, and Montenegro. Nevertheless, Sunstein reiterated his earlier analysis, contending that 'the mere existence of a secession right would fuel secessionist impulsesmaking the claim for secession more credible, and more frequent'. ${ }^{36}$ Sunstein is not hostile to independence movements as such. He recognizes, for example, 'in some cases, a right to secede will be fully justified-as a matter of political mortality', but defends 'a strong presumption against a constitutional right to secede' as a threat to the integrity of states, and a distorting influence on their democratic decision-making. ${ }^{37}$

The concept of the 'constitutional' in Sunstein's argument grafts neatly onto the United States' experience of codification, and the constitutional drafting which was being undertaken in post-Soyiet republics of the early 1990s. He defines a constitutional right to secession as 'an explicit textual provision guaranteeing such a right' or 'an implicit understanding that the constitution creates' such a right, accompanied by 'a willingness to enforce that right by a court capable of granting and enforcing a subunit's request to secede despite the objections of the central government.' ${ }^{38}$ Hoyever, these definitions, and their implications, sit much less comfortably in the modern British constitution, and the challenges of legitimate self-determination it faces. Sunstein's argument against constitutionalizing secession relies on a sharp distinction between constitutional recognition and nonrecognition of secession. But what does 'constitutional recognition' mean, in a state in which the constitution is uncodified and politically contested? ${ }^{39}$ In the

32 Sunstein, 'Constitutionalism' (n. 30) at 634.

33 Sunstein, 'Constitutionalism' (n. 30) at 634.

34 D. Weinstock, 'Constitutionalizing the right to secede' (2001) 9 The Journal of Political Philosophy 182 at 202.

35 Sunstein, 'Constitutionalism' (n. 30) at 648.

36 C. R. Sunstein, 'Should Constitutions Protect the Right to Secede? A Reply to Weinstock' (2001) 9 The Journal of Political Philosophy 350 at 354.

37 Sunstein, 'Constitutionalism' (n. 30) at 653.

38 Sunstein, 'Constitutionalism' (n. 30) at 647.

39 Sunstein, 'Constitutionalism' (n. 30) at 635. 
wake of the 2014 referendum, and the legal and political constitutional ideas embodied in the process, are the advantages of rejecting constitutional 'precommitment' available to the United Kingdom at all?

This chapter argues the category of the constitutional remains essentially politically contested and unstable in the United Kingdom. Questions of the legality, constitutionality, and justifications for calling a second referendum on the national question must be understood in that context. Examining first the proceedings of the Smith Commission, the origins of devolution in 1998, and finally the Scottish Government's strategic, limited engagement with the question of whether the 2011 referendum Bill was technically intra vires, this chapter argues that constitutional law is not an exhaustive repository of legitimating and delegitimating constitutional values. Considering both the technical and the political constitution, the constraints of the Scotland Act, and the dominant concept of Scottish popular sovereignty, the prospect of a 'neverendum' is much like the 2014 poll: primarily, and ultimately, a negotiated, contested, and ongoing question of constitutive politics.

\section{Deciding not to decide: The Smith Commission}

The hastily assembled Smith Commission report, and subsequent Scotland Bill based on its recommendations, are silent on the legal regulation of future referendums. At the insistence of its pro-independence members, Smith's final report recognized that 'nothing in this report prevents Scotland becoming an independent country in future should the people of Scotland so choose,' but said nothing about whether, when, and if such a choice might be expressed. ${ }^{40}$ Although the issue was largely missing from the agendas of Smith's elite, exclusive, and narrow plenary sessions, several individual submissions received-and largely ignored-by the Commission were preoccupied with the prospect of a future referendum, and anxious that the question should be regulated by law. Interestingly, this preoccupation was not limited either to supporters or opponents of Scottish independence, and equally tellingly, submissions articulating both points of view characteristically appealed to the idea of 'the sovereign right of the Scottish people to determine their constitutional future' to justify their preferences. ${ }^{41}$ For example, the pro-independence Yes East Ayrshire group submitted that 'the current Scottish Claim of Right signed in 1989 should be legally enacted, enshrining the Sovereignty of the People of Scotland in Law', ${ }^{42}$ while the sceptical Stay United Scotland group insisted that 'all parties must accept that the "Sovereign will of the Scottish People" is to remain part of the UK' and accordingly:

\footnotetext{
40 Smith Commission, Report of the Smith Commission for Further Devolution of Powers to the Scottish Parliament (2014) para. 18.

41 Yes Largs, Submission to the Smith Commission (2014) 2.

42 Yes East Ayrshire, The Smith Commission Scotland's Constitutional Settlement Response (2014) para. 1.1 .
} 
No further referendum on Scottish Independence should be allowed by the UK Government unless it is supported by an Act of Parliament or a specific vote in Westminster approved by two thirds of all UK MPs. Such a requirement is demanded in Spain, Australia etc because of the consequential damage to the whole of those countries from the departure of a part. ${ }^{43}$

Public submissions did little to shape the substantive Smith Commission agenda. These are, however, telling fragments of 'popular constitutional consciousness', to adapt Ewick and Silbey's celebrated phrase. ${ }^{44}$ In these largely neglected fragments, expressing ordinary people's earnest and deeply felt understandings of the law and the constitution, it is striking how the discourse of Scottish 'popular sovereignty' unites both Yes and No campaigners. Nothing better exemplifies the hegemonic status this idea now enjoys in Scottish—and arguably Britishpublic life. ${ }^{45}$ This language was also used in the final Smith Commission report itself, legitimating the hurried consensus the political parties reached in November 2014:

Reflecting the sovereign right of the people of Scotland to determine the form of government best suited to their needs, as expressed in the referendum on the 18 September 2014, and in the context of Scotland remaining within the UK, an enhanced devolution settlement for Scotland will be durable, responsive and democratic. ${ }^{46}$

In its submission to the Smith Commission, the Scottish Government argued that 'the sovereign right of the people of Scotland to determine their form of government should be enshrined in law'. ${ }^{7}$ This proposal was briefly revived by the SNP delegation at the third reading of the Scotland Bill in the House of Commons in November 2015, but was defeated. Defending the amendment, which would have invested the Scottish Parliament with the power to call another independence referendum without resort to the UK Parliament or Government, the party's Westminster leader, Angus Robertson MP, invoked the idea of Scottish popular sovereignty, arguing that;

there should only be another referendum on Scottish independence when the people of Scotland indicate that they want one, but it is right that the Scottish Parliament- the people of Scotland's Parliament-should hold the power to react to the wishes of the people of Scotland. ${ }^{48}$

43 Stay United Scotland, Submission to the Lord Smith Commission (2014) 1-2.

44 P. Ewick and S. S. Silbey, The Common Place of Law: Stories from Everyday Life (Chicago University Press 1998).

45 J. Mitchell, 'Shibboleths and Slogans: Sovereignty, Subsidiarity and Constitutional Debate', Scottish Government Yearbook 1992 (Unit for the Study of Government in Scotland, University of Edinburgh, 1992) 98-113; N. MacCormick, 'Sovereignty: Myth and Reality' (1995) 11 Scottish Affairs 1-13; J. Mitchell, 'The Narcissism of Small Differences: Scotland and Westminster' (2009) Parliamentary Affairs 1; M. Goldoni and C. McCorkindale, 'Why We (Still) Need a Revolution' (2013) 14 German Law Journal 2197-228.

46 Smith Commission (n. 40) at para. 20.

47 Scottish Government, More Powers for the Scottish Parliament: Scottish Government Proposals (2014) 2.

48 HC Deb, 9 November 2015, Vol. 602, col. 71. 
The UK Government voted down the Nationalist amendment, but has otherwise been unwilling to revisit constitutional questions temporarily foreclosed by the Edinburgh Agreement. In its submission to the Smith Commission, the Scottish Conservatives argued that 'as a nation, we must avoid future damaging and divisive debates on separatism'. ${ }^{49}$ However, the new Conservative government, elected in May 2015, has shown no enthusiasm for using the law, and their Commons majority, legally to foreclose that debate. The constitutional door has_-just-been left ajar.

\section{The origins of uncertainty: The Scotland Bill 1998}

UK politicians were not always so reluctant to consider the questions which animated Lord Smith of Kelvin's correspondents. Delving back intorthe parliamentary proceedings concerning the Scotland Act 1998 reveals that the prospect of an independence referendum, and Holyrood's constitutional authority to organize such a poll, preoccupied framers of the Act. This questionis not only of historical or political interest. It also informs a critical legal question: in 1998, did the UK Parliament intend to give Holyrood the legislative competence to call an independence referendum on its own authority? Paragraph 1 of Schedule 5 reserves 'the Union of the Kingdoms' but nowhere does the Scotland Act directly or explicitly establish that referendums on independence are ultra vires. Referendums are not listed as a reserved competence. Accordingly, under the Act's reserved powers model, competence to organize referendums is generally devolved to Holyrood. But what about organizing a more specific poll about the Union's future? To answer that question, we must consider whether the referendum 'relates to the reserved matter' of the 'Union' having regard to the referendum provision's 'purpose and effect in all the circumstances'.

Investigating the Scotland Bill proceedings in 1997 and 1998, what did Westminster intend in passing the Scotland Bill? Did it envisage that Holyrood would have the power to organize an independence referendum? That investigation produces ambiguous evidence. The first draft of the Scotland Bill, presented to Parliament by Tony Blair's Labour government after the referendum victory on 17 December 1997, had proposed a much more widely drawn restriction on Holyrood's competence over 'constitutional' matters. Paragraph 1 of Schedule 5 initially provided that 'the constitution, including the Crown, the succession to the Crown and a regency and the Parliament of the United Kingdom, are reserved matters'. In the final text adopted by parliament, however, this provision was narrowed significantly. The Scotland Act 1998 listed only 'aspects of the constitution which are reserved matters', including 'the Union of the Kingdoms of Scotland and England', the 'Parliament of the United Kingdom'-and so on. ${ }^{50}$

\footnotetext{
49 Scottish Conservative Party, Commission on the Future Governance of Scotland (2014) 1.

50 Scotland Act 1998, Sched. 5, para. 1.
} 
Given the logical structure of the Act, where powers not reserved are devolved, the clear implication of this paragraph is that there is no general reservation of power to Westminster over every issue which might be considered 'constitutional' in character.

During Commons proceedings on the Bill, the Secretary of State for Scotland, Donald Dewar, was to some extent evasive on the vires of a referendum canvassing public attitudes to Scottish independence, as opposed to unilateral legal measures purporting to tear Scotland from the United Kingdom. On 12 May 1998, Dewar was pressed on the question by MPs. Tory constitutional spokesman, Michael Ancram, put the central point clearly:

the Secretary of State mentioned the Union of the United Kingdom being a reserved matter. Does that mean that a referendum on the union also will be a reserved matter and not available to the Scottish Parliament? ${ }^{51}$

Dewar emphasized the Scottish Parliament's limited authority to enact changes to the UK constitution unilaterally. 'It is clear that constitufional change- the political bones of the parliamentary system and any alteration to that system-is a reserved matter. That would obviously include any change or any preparations for change,' he said. ${ }^{52}$ Ancram, devolution-sceptic Labour MP Tam Dalyell, and Tory MP Dominic Grieve QC pressed Dewar for a mote categorical statement. Dalyell suggested Dewar's 'charm, wit and verbal facility disguise that there has been no answer to a fundamental question' of whether the Scottish Parliament could, of itself, initiate a referendum on independence. ${ }^{53}$ The Secretary of State responded:

it is not in the power of the Scottish Parliament to change the constitutional arrangements. Scotland will of course have the right to enter into any debate about these matters in the United Kingdom Parliament, and there will be Scottish representatives to do so. That is as it should be.

Detecting 'a certain tendency to shy away from the specific question', it fell to future Attorney-General, Dominic Grieve, to prompt the clearest comment from the minister on the question of legislative competence. ${ }^{54}$ Grieve noted that 'a referendum in itself would not be a constitutional change but a mechanism of consultation' - on that understanding, 'would the holding of a referendum be within the competence of the Scottish Parliament?'55 'A referendum that purported to pave the way for something that was ultra vires is itself ultra vires,' Dewar concluded. ${ }^{56}$ Even this statement- to some extent-hedges.

By contrast, government ministers in the Lords sketched out a more decisive position. Resisting an amendment from Lord Rowallan which would have specified

51 HC Deb, 12 May 1998, Vol. 312, cols 256-7.

52 HC Deb, 12 May 1998 (n. 51) at col. 257.

53 HC Deb, 12 May 1998 (n. 51) at col. 258.

54 HC Deb, 12 May 1998 (n. 51) at col. 258.

55 HC Deb, 12 May 1998 (n. 51) at col. 258.

56 HC Deb, 12 May 1998 (n. 51) at col. 258. 
that 'the Union of the Kingdoms Scotland and England, including the holding of referendums on questions relating to the maintenance of that Union' are reserved matters, ${ }^{57}$ Lord Sewel was categorical:

as the Bill stands the Scottish parliament will not be able to legislate to hold a referendum on independence as the union of the kingdoms is already a reserved matter under Schedule 5. Explicit reference along the lines proposed by the noble Lord, Lord Rowallan, is just not needed. In determining what relates to a reserved matter, the government amendments table to Clause 28 are of help here, because they indicate that we must look at the purpose of what is being done. If the parliament passed an Act to hold a referendum about whether the Union should continue, it would thus clearly be legislating in relation to the reserved matter of the Union. Any such Act would be about the continuation of the Union and it would therefore be beyond the parliament's competence and would not be law. ${ }^{58}$

This position was reiterated in similarly uncompromising terms by the Lord Advocate. ${ }^{59}$ Significantly, this interpretation of the Bill was not accepted by the Conservative constitutional spokesman in the Lords. At the Committee stage, Lord Mackay of Drumadoon maintained that 'notwithstanding the argument explained by the Secretary of State in another place and repeated by the Lord Advocate':

it would be perfectly possible to construct a respectable legal argument that it was within the legislative competence of the Scottish parliament to pass an Act of Parliament authorising the executive to hold a referendum on the issue of whether or not those who voted in Scotland wished Scotland to be separate from the UK. ${ }^{60}$

Read in isolation, Lord Sewel's comments seem decisive against the legislative competence of any referendum bill. Read in context, however, the question remains more open. Which one of these diverse, sometimes Delphic, and conflicting statements should be treated as reflecting parliamentary intent? Although Lord Sewel's remarks were unqualified and unequivocal, his interpretation was rejected by opposition spokesmanand supported in a less than full-throated way by the minister in the democratic house, despite being given several opportunities to make such a statement. It is also instructive to note that Lord Sewel anticipated that in interpreting the 'purpose and effect' test enshrined in section 29 of the Scotland Act, the courts would draw on the 'pith and substance' doctrine employed 'in dealing with cases arising from the Commonwealth constitutions and the Government of Ireland Act 1920'. As the former president of the Court of Session, Lord Clyde, pointed out in the subsequent debate, 'purpose, to my mind, is not the same as the pith and substance'-a judgment which was vindicated in the United Kingdom Supreme Court's leading authority on the interpretation of section 29, Martin and Miller $v$ Lord Advocate. ${ }^{61}$

57 HL Deb, 21 July 1998, Vol. 592, col. 850.

58 HL Deb, 21 July 1998 (n. 57) at col. 854.

59 HL Deb, 18 June 1998, Vol. 590, col. 1787

60 HL Deb, 21 July 1998 (n. 57) at col. 852.

61 HL Deb, 21 July 1998 (n. 57) at col. 832. 
Mackay's scepticism about the force of Lord Sewel's analysis draws strength from the imprecision of Sewel's analysis of the text of the Bill, and other important provisions of the legislation which he failed to mention. As the courts have subsequently recognized, the 'relates to a reserved matter' test cannot be parsed as referring to legislation which is 'about' reserved matters, but 'indicates something more than a loose, consequential connection' with them. ${ }^{62}$ The analysis of parliamentary proceedings leaves the status of a referendum where it began: arguable, clearly strengthening the case of those who argue such a referendum would be unlawful, but with too many inconsistencies and ambivalences to answer the matter conclusively.

\section{The two constitutionalisms of Scottish Nationalism}

Before proceeding to examine the constitutional ideas mobilized by the Scottish Government in 2012, and likely to be mobilized in support of any future referendum, it is instructive first to consider the Scottish National Party's more general constitutional politics, from which its referendum strategy emerged. For the Nationalist leadership, what does a good constitution look like? What characteristics does it have? Speaking at the Edinburgh Centre for Constitutional Law in June 2014, Nicola Sturgeon outlined her vision for the constitution of an independent Scotland:

We believe that Scotland should have a written constitution, rather than the quilt work of statutes, precedent, practice and tradition that make up the constitution of the UK. A written constitution provides certainty and security for the citizens of a state. It defines and constrains the organs of the state. It describes where power lies and how those who wield it are chosen and scrutinizéd. As is well known, this is not always clear in the UK. ${ }^{63}$

In their criticism of the constitutional status quo in Britain, and preference for a codified, entrenched and judicially enforceable basic law, Sturgeon's remarks are characteristic of contemporary Nationalist constitutional thinking. In earlier remarks to the Foreign Press Association in January 2013, Alex Salmond explicitly tied claims of Scottish popular sovereignty to a critique of the United Kingdom's constitutional practices. Citing the 1320 Declaration of Arbroath and the 1989 Claim of Right as evidence of a 'centuries' old and 'distinct' Scottish constitutional tradition, Salmond argued:

That tradition states that the people of Scotland are sovereign and that they have the power to determine the form of government best suited to their needs. It stands in contrast to the UK principle that parliament has unlimited sovereignty. That UK tradition is one of the reasons that the UK has no written constitution. That makes the UK highly

62 Recovery of Medical Costs for Asbestos Diseases (Wales) Bill: Reference by the Counsel General for Wales [2015] UKSC 3 at para. 25 per Lord Mance.

63 N. Sturgeon, 'The Constitutional Future of an Independent Scotland', speech given at the Edinburgh Centre for Constitutional Law, 16 June 2014. 
unusual among Western democracies, and unique within the European Union. That deficiency is a democratic deficit that an independent Scotland should not repeat. ${ }^{64}$

Nationalist constitutional discourse has tended to emphasize the precarious legal status in which devolved institutions are left by the principles of Westminster sovereignty and non-entrenchment of the Scotland Act. Another Nationalist MSP, writing in a popular tabloid newspaper in 2015, exemplifies this attitude:

The UK does not have a written constitution protecting the rights of the different countries that make up the Union. If it did, Scots could challenge a move to kill off their parliament as unconstitutional. As things stand, we are at the mercy of a House of Commons. ${ }^{65}$

What often goes unnoticed, however, is how far Nationalist politicians have employed the very constitutional flexibility they deride to promote their political ambitions within the United Kingdom since 1998. Aspirationally, Nationalist politicians may be legal constitutionalists. As cold-eyed pragmatists, however, the United Kingdom's political constitution has done a great deal more to accommodate their demands than any codified UK constitution which more definitively delimited the powers and privileges of Scottish institutions on the one hand, and shared UK institutions on the other. As Lord Reed held in Imperial Tobacco, 'the Scotland Act is not a constitution, but an Act of Parliament, ${ }^{66}$ While non-entrenchment must mean that Holyrood is, legally, vulnerable to abolition, it also means that the current limits to Holyrood's powers cannot be justified with reference to any higher law. They remain, always, a matter of pollitical choice. An uncodified UK constitution cannot formalize the principle of 'Scottish popular sovereignty' invoked by Alex Salmond, but nor can it decisively exclude it. The category of the constitutional remains essentially politically contested, and unstable. This instability is reflected in the gradual elaboration of Holyrood's powers since 1998 by successive Scotland Bills, and most vividly of all, by the volte face which invested the Scottish Parliament with clear legal authority to organize a referendum on Scottish independence in 2014. The Scottish Government's arguments during this period are of more than historical interest. They sketch, in outline, the constitutional attitudes liable to inform any attempt to revisit the national question in a second referendum.

\section{Boxing shadows: The technical Jekyll and the political Hyde}

The Scottish Government's substantive legal analysis of the vires of their various referendum questions remained inscrutable throughout debates on the legislative

\footnotetext{
64 A. Salmond, 'Constitutional rights', speech given at the Foreign Press Association, London, 16 January 2013.

65 J. McAlpine, 'Westminster can't be trusted with the Scottish Parliament' Daily Record (17 June 2015).

${ }^{66}$ Imperial Tobacco v Lord Advocate [2012] CSIH 9 at para. 71.
} 
competence of the first referendum. Scottish Ministers proved consistently reluctant to recognize that the question of legislative competence was even open to question, arguing their proposals were intra vires while emphasizing broader claims of legitimate self-determination and democratic decision-making. Its 2010 Scotland's Future: Draft Referendum (Scotland) Bill Consultation Paper noted that:

Scottish Parliament legislation must conform to the provisions of the Scotland Act 1998. The Scotland Act has in-built flexibility so that the Scottish Parliament's powers can be extended over time. The Scottish Parliament has a role in such processes, for example in relation to orders made under section 30 of the Act. It is therefore legitimate for a referendum held under an Act of the Scottish Parliament to ask the people questions related to an extension of its powers insofar as this is within the framework of the Scotland Act. ${ }^{67}$

The later Your Scotland, Your Referendum Consultation (2012) observed that:

a wide range of opinion has been expressed about whether or not the Scottish Parliament has the power to hold a referendum consulting the Scottish people about independence. The Scottish Government has previously published a referendum question asking whether the powers of the Scottish Parliament should be extended to enable independence to be achieved. That question was carefully phrased to comply with the requirements of the Scotland Act 1998. Much independent legal opinion supports the Scottish Government's view. ${ }^{68}$

Notably, the Scottish Government failed to provide even a single example of legal opinion which supported the idea that what it was proposing fell 'entirely within legislative competence'.69 The consultation included a grudging and carefully worded note of conciliation, observing that the SNP were 'ready to work with the UK Government to remove their doubts about the competence of the Scottish Parliament and to put the referendum effectively beyond legal challenge'. ${ }^{70}$ The Scottish Government's legal analysis was never explained in public-a failure criticized by pro-Union Westminster committees. The Scottish Affairs Committee found 'the silence' of the Lord Advocate on the vires of the Bill 'remarkable', noting that while

it is well understoodthat Law Officers do not, save exceptionally, make their advice public, but, on a matter such as this, there is a very strong public interest in understanding the legal basis of the Scottish Government's approach to a process which will determine the future of the country. ${ }^{71}$

The House of Lords Select Committee on the Constitution found it similarly 'regrettable that the Scottish Government have not set out their legal position more fully' ${ }^{72}$ This reticence is not altogether surprising. Although this has never

67 Scottish Government, Scotland's Future: Draft Referendum (Scotland) Bill Consultation Paper (2010) para. 1. 26.

68 Scottish Government, Your Scotland, Your Referendum Consultation (2012) 4-5.

69 Scottish Government, Your Scotland (n. 68) 5.

70 Scottish Government, Your Scotland (n. 68) 5 (my emphasis).

71 Scottish Affairs Committee, The Referendum on Separation (n. 13), at para. 25.

72 House of Lords Select Committee on the Constitution, Referendum on Scottish Independence (n. 13) at para. 10. 
been publicly confirmed, it is understood that the Scottish law officers advised ministers that the proposed referendum legislation would not withstand judicial scrutiny under section 29 and Schedule 5 of the Scotland Act and that Westminster cooperation would be necessary to escape the significant risk of litigation. One can understand why Scottish ministers were disinclined to meditate on these questions in public. This reticence extended to the Scottish Nationalists' decision not to deploy their majorities on critical Holyrood committees to pursue investigations to parallel the Lords and Commons reports on the vires of the referendum under the Scotland Act. Their tactical reasons for not doing so were twofold. Firstly, even in committees with SNP majorities, Holyrood committees were always more heterodox on the national question than their London equivalents. Given their cross-party membership, they could not be expected to fulfil the same partisan, campaigning function as the uniformly pro-Union committees of Scottish Labour MP, Iand Davidson, and Baroness Jay.

Secondly, public discussion of the legislative competence of the referendum would have cut against the SNP's wider, characteristically disciplined shadowboxing strategy, which made no public concessions as to legislative competence whatever. Any fair-minded, evidence-based investigation of the vires questions would inevitably generate and publicize doubts about the competence of the referendum legislation, even if legal voices could have been produced to make the case that 'a plausible case can be made that such a Bill would be lawful'.73 Ignorance was exploited and message-discipline maintained by ensuring that vires issues remained poorly ventilated and poorly understood. That this was even possible reflects the extent to which the deyolution settlement in Scotland, and the role and powers of the courts within it, is poorly understood by the public, and indeed, by the political commentators who help shape legal and political consciousness through the national and local media.

This limited comprehension and regard for the limits of the Scotland Act perhaps explains the frustrated tone which characterized the numerous warnings advanced by the Advocate General for Scotland before October 2012. Warning in January of that year that 'wherever law ends, tyranny begins,' Jim Wallace invoked 'the importance of upholding the Rule of Law' in the referendum process, opposing the idea 'that legal technicalities' about reservations of power under the Scotland Act 'shouldn't get in the way of the Scottish Parliament going full steam ahead' with the referendum. ${ }^{74}$ Although no prominent SNP politician had explicitly committed the party, the parliament, or the government to pressing on without Westminster consent, Wallace's warnings should be understood as a response

\footnotetext{
73 G. Anderson, C. Bell, S. Craig, A. McHarg, T. Mullen, S. Tierney, and N. Walker, 'The Independence Referendum, Legality and the Contested Constitution: Widening the Debate' (UK Constitutional Law blog, 31 January 2012) available at <http://ukconstitutionallaw.org/2012/01/ 31/gavin-anderson-et-al-the-independence-referendum-legality-and-the-contested-constitutionwidening-the-debate/>.

74 J. Wallace, 'Looking Forwards' (n. 13).
} 
to the public debate in the pages of newspapers and on social media in 2011 and 2012, which increasingly speculated on the possibility of Holyrood pressing ahead with a referendum, even if the coalition government in Westminster refused to come to terms.

But why did Nationalist politicians refuse, in public at least, to engage with these fundamental questions about the distribution of powers in the British constitution, and the perils of litigation? Their strategy-their constitutional omertà-arguably reflected a recognition that constitutional law is not an exhaustive repository of legitimating and delegitimating constitutional values. Nationalist politicians calculated, correctly, that the powerful 'political orthodoxy' of Scotland's right to self-determination would answer the significant, but ultimately politically indefensible, legal hurdle represented by an unfavourable interpretation of Schedule 5 of the Scotland Act, if not in the Supreme Court, then in Parliament and Whitehall. ${ }^{75}$ The force of this politicalconstitutional orthodoxy also helps to explain the strange absence of any technical constitutional debate from the ongoing, sometimes heated, political debate about the conditions which might provoke a second referendum on the national question. For all of the fanfare and coverage of the Edinburgh Agreement, it signally failed to entrench in the popular consciousness that the United Kingdom Government and Parliament had and has a legitimate, countervailing interest in whether and when referendums are held concerning the integrity of its territory. ${ }^{76}$ In an entrenched constitution, with cumbersome or difficult amendment protocols, the UK Government might have found constitutional resources to resist the referendum. But if, as Lord Reed concluded, the Scotland Act is 'not a constitution' but only an emanation of Westminster's legislative will, constitutional recognition of the Scottish people's constitutive power becomes a matter of political choice. ${ }^{77}$

There is little evidence that pro-Union politicians ever seriously contemplated a strategy of constitutional resistance to Scottish demands for self-determination. As Colin Kidd has argued, the intellectual tradition of Scottish nationalism and Unionism should not be conceptualized as binary opposites, sharing nothing in common, but as overlapping traditions, sharing a number of political premises. Graeme Morton has identified a 'Unionist-nationalism', which favours the retention of the Union, but which emphasizes the importance of Scottish distinctiveness within its confines, rejecting conceptions of the Union as incorporating or producing a unitary state within which Scottish claims to distinctiveness are effaced..$^{78}$ A contemporary version of this conception of union was of fundamental

\footnotetext{
75 A. Tomkins, 'Scotland's Choice, Britain's Future' (2014) 130 Law Quarterly Review 215 at 220 .

76 An argument advanced by N. Barber, 'After the vote: regulating future independence referendums' (UK Constitutional Law blog, 21 March 2014) accessible at <http://ukconstitutionallaw.org/ 2014/03/21/nick-barber-after-the-vote-regulating-future-independence-referendums/>.

77 Imperial Tobacco $v$ The Lord Advocate [2012] CSIH 9, per Lord Reed at para. 70.

78 G. Morton, Unionist-Nationalism: Governing Urban Scotland 1830-1860 (Tuckwell Press 1999).
} 
importance to the broad consensus in 2012 on the legitimacy of Holyrood posing the national question. The Claim of Right was, after all, not a Nationalist document but a declaration to which a great number of Scottish independence's most inveterate opponents put their names in 1989. As Tomkins has argued, for adherents of the Diceyan tradition, 'as a matter of strict law the Claim of Right is heresy'. ${ }^{79}$ In the popular constitutional consciousness, by contrast, it is orthodoxy and right-reason. The right to self-determination invoked by the Scottish Government in 2011 and 2012 was not novel, or essentially contested, but had already been politically mainstream and entrenched in Scottish public life for at least three decades, if not longer. The language of self-determination undergirded the decision to establish a Scottish parliament in 1998, and the role of a referendum in sanctioning its creation. By treating the referendum as self-evidently politically legitimate, the Scottish Government implicitly popularized the claim that it must be equally self-evidently legally legitimate-which is to say, lawful under section 29 of the Scotland Act.

Although cynical, and hardly candid, this was not an inherently unreasonable or unstrategic position for Nationalist politicians to adopt. After the Holyrood election of 2011, the attitude of the UK Government and Parliament to the legitimacy of the proposed poll could not entirely be taken for granted. Within living memory, during the Scotland Bill debates of $1997-8$, UK ministers had envisaged that Holyrood would not, and should not, have the power to organize a referendum on its own authority. Scotland's right unilaterally to exercise selfdetermination remains open to question in international law. ${ }^{80}$ It was not selfevident that ministers and MPs from açross the United Kingdom would accept the SNP's democratic mandate for a poll and prove willing to take legislative steps to facilitate a referendum. Spanish attitudes to the plebiscite on Catalan self-government represented/a salutary object lesson in the constitutional trench resistance which the United Kingdom might have exercised in defence of its territorial and political infegrity. SNP politicians avoided making public concessions which could have proved damaging in any future legal proceedings, if the UK Government's broadly deferential approach to Scottish self-determination had not been maintained.

In 2000, the late Neil MacCormick argued that 'it is a very particular virtue of the Scottish national movement always to have discountenanced any apparent shortcuts. Instead, it has stuck doggedly to a democratic and constitutional path, whatever obstacles this involved in the way of electoral disadvantage under the dominance of hostile media'. ${ }^{81}$ UK constitutional resistance to the 2014 referendum would have placed this commitment under unprecedented strain and have thrown open a constitutional and political Pandora's Box. During this period, the UK Advocate General, Jim Wallace, made several public interventions,

\footnotetext{
79 Tomkins, 'Scotland's Choice' (n. 75) at 220.

80 See Bell, Ch. 9 in this volume, at 200-3.

81 N. MacCormick, 'Is There a Constitutional Path to Scottish Independence?' (2000) 53 Parliamentary Affairs 721 at 721.
} 
arguing that the referendum was ultra vires. Would he use his authority under the Scotland Act to refer the matter directly to the Supreme Court to vindicate his view, striking down the Act and exposing him and his government to intense political pressure and criticism? Alternatively, would he await the efforts of a private citizen challenging the referendum, and the prospect of protracted and damaging litigation which that would inevitably entail? For Unionists, this was a nightmare scenario-a scenario which would inevitably have been taken less seriously, had the Scottish Government not robustly maintained its intention to press on with the poll, come what may. The UK Government was left with only two options: either facilitate a lawful poll, or face the prospect of trying (and probably failing) to prevent the Nationalists organizing the referendum anyway while exposing UK institutions to allegations of anti-democratic attitudes. In defence of constitutionalizing the right to self-determination, Daniel Weinstock describes the 'prudent constitution-makers', who make legal provision' for a poll as 'a way of controlling a process which would otherwise happen anyway in a much less manageable, and potentially more destructive manner' ${ }^{82}$ The Edinburgh Agreement process is an object lesson in this kind of prudential constitutional calculation.

In the light of this lopsided non-debate, it is perhaps unsurprising that contemporary mediations on the prospect of a future referendum tend to assume the attitude criticized by Jim Wallace in 2011, waving aside 'legal nit-picking' and nice questions of statutory interpretation:83 Because of the Scottish Government's calculated reticence to embark on a detailed legal defence of its authority to call a referendum, the arguments in favour of an intra vires reading of a future referendum poll remain largely unventilated. ${ }^{84}$ It is perhaps unsurprising, therefore, that the political debate and counter-debate about the rights, wrongs, calculations, and triggers informing a decision to hold another referendum continue to ignore the technical constitution almost entirely. Sunstein suggests that 'the mere existence of a secession right would fuel secessionist impulses-making the claim for secession more credible, and more frequent'. ${ }^{55}$ However, the ongoing UK experience arguably vindicates Weinstock's more sceptical analysis of Sunstein's emphasis on the particular perils on constitutionalizing secession rights. 'Secessionist politics' Weinstock argued, 'will occur anyway, regardless of legal silences and prohibitions' ${ }^{86}$ Indeed, by having no groundwork of agreed legal principles, establishing a timeline and conditions on which another referendum might be held, arguably gives Scottish Nationalists greater scope to issue threats and menaces about precipitating a second referendum than might otherwise be the case.

\footnotetext{
82 Weinstock, 'Right to Secede' (n. 34) at 202.

83 Wallace, 'Looking Forwards' (n. 13).

${ }^{84}$ A point made eloquently at the time in an influential academic intervention by a number of contributors to this book: Anderson, Bell, Craig, McHarg, Mullen, Tierney, and Walker (n. 73).

85 Sunstein, 'Reply to Weinstock' (n. 36) at 354.

86 Weinstock, 'Right to Secede' (n. 34) at 196.
} 


\section{Navigating towards a neverendum, without a map or compass}

The outcome of this meditation is in many ways paradoxical. Considered exclusively from a legal point of view, in terms of the technical constitution, the devolution legislation, and the Court's approach to the interpretation of the Scotland Act, the emphasis is on the 'never' in 'neverendum'. While a further secession poll is not explicitly banned under the Scotland Act, and an arguable case may still be constructed in defence of the legality of such a poll, any pro-independence future Scottish Government and Parliament faces-perhaps insuperable-legal hurdles unless Westminster consent and acts to facilitate another referendum.

However, constitutional law is not an exhaustive repository of constitutional values. In the wake of the 2014 referendum, we are left with an ambivalent combination of 'constitutional recognition' and non-recognition of Scottish secession rights. ${ }^{87}$ At the time of writing, the new Scotland Bill remains under scrutiny, subject to amendment and change. But in the Bill's earfy months before parliament, there seems little appetite to anticipate what to many critics and commentators now seems inevitable, and to take the opportunity to pre-commit to the legality of a future independence poll. A conscious policy choice has been made to leave the question of the legality of any future referendum open, ad hoc, and uncertain. If the technical constitution is ambivalent about Scottish rights to selfdetermination, Unionist or nationalist, pro- or anti-independence-the political culture is not. The recognition of the sovereign right of the Scottish people to determine the form of government best suited to their needs's8 may be 'extratextual and nonjusticiable', ${ }^{89}$ yet it has, if anything, been more deeply entrenched by the 2014 referendum than it has been at any point in history before. This Jekyll and Hyde dyad leaves the constitutionality, if not the legality, of future referendums in the half-twilight, caught between a technical analysis of the Scotland Act and the powers it confers, and a largely uncontested political claim that the Scottish people have the right to decide how they are governed.

In Sunsteins terms, the right to secession is at once recognized and not recognized. This constitutional duality is perhaps an inevitable consequence of the United Kingdom's uncodified basic law. Having constitutionally legitimated ideas of popular Scottish sovereignty, that recognition is extremely difficult to reverse in the short and medium term, whatever technical restrictions are articulated in the Scotland Act. Yet the political behaviours Sunstein fears - using threats of secession as tools of political strategy, examining day-to-day policy decisions through the prism of national and constitutional questions - arguably already characterize post-referendum UK politics. This is reflected by the pervasive logic of 'triggers' for a second referendum,

\footnotetext{
87 Sunstein, 'Constitutionalism' (n. 30) at 635.

88 Smith Commission (n. 40) at para. 20.

89 Sunstein, 'Constitutionalism' (n. 30) at 633.
} 
transforming questions of European Union reform, or defence policy, into constitutionally provoking events. Yet in a constitutional sense, all of these debated 'triggers' are essentially transient factors whose importance can be contested. Woven together, they may contribute to the justificatory fabric of demands to revisit the national question in a national plebiscite. Yet only the idea of Scottish popular sovereignty represents a constitutional sine qua non for a second referendum.

So why leave the future regulation of independence referendums to chance? Why defer a political conflict which, to many, now seems inevitable? Lawyers are sometimes inclined to treat the idea of legal indeterminacy as inherently problematic, and to demand further codification, further clarification, greater legal 'pre-commitment' - as if these things are self-evident goods in statecraft and governance. Lord Bingham expressed the sense of jurisprudential forlornness in the absence of legal regulation particularly vividly. In an essay on written constitutions, he said 'constitutionally speaking, we now find ourselves in a trackless desert without map or compass. ${ }^{90}$ But is this legal maplessness the substantial problem which some lawyers may be tempted to claim? The limits of legal regulation may certainly be uncomfortable. It can precipitate crises. In 2011, after the election of a pro-independence majority in Holyrood, these dubieties in the law were undeniably problematic. Yet when the politicalmandate and political will to organize an independence referendum met the strictures and ambivalences of the Scotland Act-Westminster yielded. In response to legitimate political claims, politics (temporarily) remoulded the law.

This approach is at least defensible, both from pro-independence and pro-Union perspectives. By declining to put the matter beyond doubt, whether through caution, calculation, or principle, Westminster ensures that the legal, political, and constitutional question-can Holyrood ordain another referendum?-remains an open one until a concrete proposal materializes. The ambivalence of the status quo continues to afford a future Westminster government some leverage on question, timing, and terms. In parallel, the political domination of claims to legitimate self-determination mean that patient and impatient supporters of Scottish independence need not be too preoccupied by the non-recognition of secession rights in the Scotland Bill. The constitutional debate remains unforeclosed. This represents an uneasy kind of constitutional truce.

Perhaps this is as it should be. In a letter to James Madison in September 1789, Thomas Jefferson wrote that 'the earth belongs in usufruct to the living' and 'that the dead have neither powers nor rights over it. 91 We can express this thought more simply: law cannot strip democratic politics of its inherent uncertainty and instability. Negotiation may be preferable, and less apt to generate insoluble political crises, than maladapted constitutional 'determinacy and rule-governedness. ${ }^{92}$

90 T. Bingham, 'A Written Constitution?' in Lives of the Law: Selected Essays and Speeches (Oxford University Press 2011) 97.

${ }_{91}$ Quoted in H. Sloan, 'The Earth Belongs in Usufruct to the Living' in P. S. Onuf (ed.), Jeffersonian Legacies (University of Virginia Press 1993) 281.

92 H. Aronovitch, 'Seceding The Canadian Way' (2006) 34 The Journal of Federalism 541 at 560. 
The spectre of a 'neverendum' rose immediately from the grave of the 2014 poll, as independence supporters were smarting, and as Better Together campaigners sighed relief. As Weinstock argues, in defence of the idea of constitutionalizing secession rights:

there are occasions in the political history of a community when the fund of good will and trust is sufficient to make or amend a constitution in such a way as to incorporate a right to secede, and there are times when all suggestions will be viewed with suspicion.

In the wake of the 2015 general election, the necessary elements of trust and goodwill seem in short supply. But in our Jekyll and Hyde constitution, deferring these questions until tomorrow, dealing with them concretely rather than in the abstract, may ultimately be the most prudent, the most politically adroit, response to Scotland's changed politics and now unsettled constitutional will. For both proponents and opponents of Scottish independence, arguing their cases under the political constitution of the United Kingdom, 'the campaign continues, and the dream shall never die., ${ }^{33}$

93 BBC News, 'Scottish referendum: Salmond to quit after Scots vote No' (19 September 2014) accessible at <http://www.bbc.co.uk/news/uk-scotland-29277527> last accessed 29 November 2015. 